日本組織学記録, 巻 25 , 号 2 , (昭和 39 年 12月). 頁 145-163.

Arch. histol. jap. Vol. 25, n. 2 (October 1964). P. 145-163.

岡山大学医学部, 第 1 解剖学教室 (主任：尾兽越教授) と

山口大学医学部, 第 1 解剖学教室 (副主任: 粟屋助教授).

Ist Dept. of Anat. (Head: Prof. B. OSOGOE), Okayama University Med. Sch., Okayama and

Ist Dept. of Anat. (Subhead: Assist. Prof. K. AWAYA), Yamaguchi Univ. Sch. of Med., Ube.

\title{
Wistar 系ラットに和ける造血組織の年令による変化
}

\section{Age Changes in the Blood-Forming Tissues in the Albino Rat of a Subline of the WISTAR Strain.}

小田正義 Masayoshi ODA.

(Received September 15, 1964.)

造血組織, とくに胸腺リンパ組織の生後の発育と退縮の過程をしらべた研究は 数多くみられる。その主なあのをあげると, 胸腺に関するあのでは（括弧内は年 号と材料) Hammar (1905, 人など), Söderlund と Backman (1909, 家志), 渡辺 (1929, ラット), 加藤 (1943, ラット), 加納 (1955, ラット), 伊東 (1957, モルモッ 卜), 伊東 (1957, 家兔), 高見 (1958, マウス), 川崎 (1959, 八ムスター); リンパ 節に関するものでは Andrew と Andrew (1948, ラット), Gyllensten (1950, モル モット)，脾に関するあのでは Groll と Krampf (1920, 人), Hellman (1930, 人), Hwang ら (1938, 人), Krumbhaar と Lippincott (1939, 人), Österlind (1940, 家 克), Andrew (1946, ラット), Gyllensten (1950, モルモット); 胸腺リンパ組織を 一括して観察したものでは Grieshammer (1937，乳幼児)，Andreasen (1943，ラッ ト), 尾曽越ら (1953, 家兔), Awaya (1956, 家鬼), Imamura (1959, ラット), Santisteban (1960，マウス); 骨骾に関するものでは Fand と Gordon (1957, モルモッ ト), Burke と Harris (1959, ラット) らの観察がある. 上に挙げた多数の研究の うちで, Andreasen (1943) の研究は胸腺リンパ組織の年令による変化を定量的 に調べたものとして特に注目される。乙れはラットの胸腺リンパ組織における DNA 燐含量を化学的に定量して組織における有核細胞の多寡を判定し, その成 績を基盤として, 胸腺は生後 2 月目まで, リンパ節と脾は生後 $3-4$ 月目まで高 度に発育するが，その後は退化することを示したあのである。そのほかの研究者 の観察の結果も造血組織が生後すみやかに発育し，比較的早期に退化するという 点ではほぼ一致しているようである，とてろが，最近，胸腺はリンパ組織の発生 や機能の面において支配的な位置を占めることが明らかになってきた，すなわち， 動物の新生児期に胸腺を摘出すると，乙れらの動物は脾やリンパ節など，他のリ ンパ組織の発育不全をきたし, 異種蛋白刺激や同種移植に対し抗体をつくること ができなくなり (Archer と Pierce 1961, Miller 1961, 1962, Martinez ら 1962, Janković ら 1962, Arnason ら 1962, 1962, Dameshek 1962, Burnet, 1962, Good ら 
1962, Dalmasso ら 1963), 且つ胸腺摘出後の発育が悪く, いわゆる wasting disease におちいり，早期に死亡する（Good ら 1962, Waksman ら 1962, Parrott と East, 1962, 1964, Sherman ら 1962, 1963). これらのととは胸腺リンパ系における胸腺 の特異性を示すあので, 胸腺の発育と退縮の過程は他のリンパ性器官におけると は著しく異なることが推定される。したがって, との際, 造血組織の生後の発育 と退縮の問題をあう一度検討しなおすとと屯意義のあることと思われる.

われわれの教室では骨䯣や胸腺リンパ組織における有核細胞の密度と総数とを 算定するととにより造血組織の定量的研究を行なってきたが，われわれはこの方 法が造血組織の年令による変化の判定法としては組織の DNA 燐含量の化学的 定量法 (上述の Andreasen 法) に匹敵することを確認した（Awaya ら 1960, 1962, Awaya 1962, 粟屋 1963). そこで, 著者はこの方法による定量的知見を主体とし, これに組織学的検索による定性的知見を加味して造血組織の年令による変化を考 察してみたいと思う。

\section{I. 材 料 と方法.}

実験動物. 実験に用いた動物は生後 1,2,3,4 週目ならびに生後 2, 3, 4, 5, 6, 8, 12, 18 月目の雌雄各 5 例, 計 120 匹の健康な正常ラットで, これらのラットはい ずれあわれわれの教室で一定の条件のあとに一定の飼料によって数年にわたり飼 育したWistar 亜系ラットのコロニーから集団交配によって得られたものであ る。飼料は玄米, 押麦および干鮙よりなり，乙れに少量の肝油と食塩および炭酸 石灰を加えて与えた．雌雄を別々に観察したのは造血組織の性差を観察するため であった。

造血組織における有核細胞の密度と総数の算定法。乙の方法の骨子はつぎの如 くである. 動物を撲殺したのち, 造血組織の一定量 ( $20 \mathrm{mg}$ 内外)をとり出し, 骨 髄は市販の人血プラスマ液の中に, また胸腺, 腸間膜根リンパ節および脾は N/4 Hcl 液の中に入れて, それぞれの組織の細胞懸濁液をつくり，血球計算と同様に して組織 $1 \mathrm{mg}$ 当たりの有核細胞数 (以下細胞密度と記す) を算定し, てれに各器 官の重量を乗じて，それぞれの器官の有核細胞総数を算出した。乙の際，1匹の ラットの骨髄の総重量は渡辺 (1955) 飞従って体重の $1.65 \%$ として算出した。 こ れらの操作の詳細はすでに粟屋ら $(1960,1962,1962)$ が記載しているのでこてで は省略する。

組織学的-細胞学的観察法. 組織は Zenker-ホルモール液で固定し, パラフィン 包埋後 5一6 の切片とし, ヘマトキシリン-エオジン染色を施して検鏡した。ま た，それぞれの造血組織の捺印標本をつくり，Wright 染色を施して細胞学的検萦 あ行なった，右大腿骨髄を細胞総数の算定に，左大腿骨髄を組織学的検索に用い た. 


\section{II. 結 果.}

\section{A. 体重の生後変化 (表 1, 図 1).}

体重は雌雄ともに生後 2 月から 8 月にかけて急増し，その後は生後 12 月に至る まで漸増し，のち徐々に減少する。生後 3 月までには性差はほとんど認められな いが，生後 4 月以後になると著明な性差がみられ，雄が雌の体重をはるかにしの いでいる.

\section{B. 定量的な面からみた造血組織の年令による変化.}

a) 胸腺（表 1,2 ; 図 2,6,7).

胸腺の重量は, 生後 2 月目に急増し, 雌では 3 月目に, 雄では 4 月目に最大と なり，その後減少する，胸腺の細胞密度は，生後 1 週目からすでに高い值を示し， このような高い值 $\left(4.0-3.2 \times 10^{6} / \mathrm{mg}\right)$ は生後 6 月まで維持されるが， 8 月以後漸 減し，12月以後急減する，有核細胞総数は，生後 2 月から急増し，雌では 3 月目

Table 1. Body weight and organ weight of the thymus, mesenteric lymph nodes, spleen and bone marrow of male and female albino rats of a modified

WISTAR strain at various ages (means of measurements, $n=5$ ).

\begin{tabular}{|c|c|c|c|c|c|c|}
\hline \multicolumn{2}{|c|}{ Age and sex } & \multirow{2}{*}{$\begin{array}{c}\begin{array}{c}\text { Body weight } \\
(\mathrm{g})\end{array} \\
\begin{array}{c}9 \\
9\end{array}\end{array}$} & \multirow{2}{*}{$\begin{array}{c}\begin{array}{c}\text { Thymus } \\
\text { (mg) }\end{array} \\
19 \\
21\end{array}$} & \multirow{2}{*}{$\begin{array}{c}\begin{array}{c}\text { Mesenteric } \\
\text { lymoh nodes } \\
(\mathrm{mg})\end{array} \\
5 \\
7\end{array}$} & \multirow{2}{*}{$\begin{array}{r}\begin{array}{c}\text { Spleen } \\
\text { (mg) }\end{array} \\
32 \\
28\end{array}$} & \multirow{2}{*}{$\begin{array}{c}\begin{array}{c}\text { Bone marrow } \\
(\mathrm{mg})^{*}\end{array} \\
\begin{array}{c}160 \\
150\end{array}\end{array}$} \\
\hline 1 week & $\begin{array}{l}\hat{0} \\
\text { oे }\end{array}$ & & & & & \\
\hline 2 weeks & $\begin{array}{l}\hat{0} \\
\text { 우 }\end{array}$ & $\begin{array}{l}17 \\
20\end{array}$ & $\begin{array}{l}54 \\
64\end{array}$ & $\begin{array}{l}10 \\
24\end{array}$ & $\begin{array}{l}45 \\
60\end{array}$ & $\begin{array}{l}290 \\
340\end{array}$ \\
\hline 3 weeks & $\begin{array}{l}\hat{0} \\
\text { 우 }\end{array}$ & $\begin{array}{l}26 \\
28\end{array}$ & $\begin{array}{l}94 \\
76\end{array}$ & $\begin{array}{l}32 \\
59\end{array}$ & $\begin{array}{r}93 \\
112\end{array}$ & $\begin{array}{l}430 \\
470\end{array}$ \\
\hline 4 weeks & $\begin{array}{l}\hat{O} \\
\text { oे }\end{array}$ & $\begin{array}{l}35 \\
34\end{array}$ & $\begin{array}{l}86 \\
97\end{array}$ & $\begin{array}{l}56 \\
68\end{array}$ & $\begin{array}{l}88 \\
98\end{array}$ & $\begin{array}{l}570 \\
570\end{array}$ \\
\hline 2 months & $\begin{array}{l}\hat{\delta} \\
\text { 우 }\end{array}$ & $\begin{array}{l}124 \\
100\end{array}$ & $\begin{array}{l}215 \\
224\end{array}$ & $\begin{array}{l}186 \\
208\end{array}$ & $\begin{array}{l}294 \\
266\end{array}$ & $\begin{array}{l}2050 \\
1660\end{array}$ \\
\hline 3 months & $\begin{array}{l}\hat{\delta} \\
\text { + }\end{array}$ & $\begin{array}{l}156 \\
156\end{array}$ & $\begin{array}{l}216 \\
292\end{array}$ & $\begin{array}{l}174 \\
224\end{array}$ & $\begin{array}{l}468 \\
562\end{array}$ & $\begin{array}{l}2580 \\
2580\end{array}$ \\
\hline 4 months & $\begin{array}{l}\hat{o} \\
\text { 우 }\end{array}$ & $\begin{array}{l}242 \\
169\end{array}$ & $\begin{array}{l}291 \\
236\end{array}$ & $\begin{array}{l}431 \\
354\end{array}$ & $\begin{array}{l}522 \\
504\end{array}$ & $\begin{array}{l}4000 \\
2780\end{array}$ \\
\hline 5 months & $\begin{array}{l}\hat{\jmath} \\
\text { 우 }\end{array}$ & $\begin{array}{l}262 \\
206\end{array}$ & $\begin{array}{l}201 \\
198\end{array}$ & $\begin{array}{l}260 \\
330\end{array}$ & $\begin{array}{l}596 \\
576\end{array}$ & $\begin{array}{l}4330 \\
3400\end{array}$ \\
\hline 6 months & $\begin{array}{l}\hat{O} \\
\text { o }\end{array}$ & $\begin{array}{l}295 \\
222\end{array}$ & $\begin{array}{l}182 \\
222\end{array}$ & $\begin{array}{l}264 \\
330\end{array}$ & $\begin{array}{l}662 \\
560\end{array}$ & $\begin{array}{l}4870 \\
3660\end{array}$ \\
\hline 8 months & $\begin{array}{l}\hat{o} \\
\text { 우 }\end{array}$ & $\begin{array}{l}408 \\
264\end{array}$ & $\begin{array}{l}186 \\
173\end{array}$ & $\begin{array}{l}228 \\
183\end{array}$ & $\begin{array}{l}534 \\
466\end{array}$ & $\begin{array}{l}6730 \\
4350\end{array}$ \\
\hline 12 months & $\begin{array}{l}\hat{O} \\
\text { ㅇ }\end{array}$ & $\begin{array}{l}450 \\
297\end{array}$ & $\begin{array}{l}115 \\
106\end{array}$ & $\begin{array}{l}194 \\
157\end{array}$ & $\begin{array}{l}631 \\
541\end{array}$ & $\begin{array}{l}7520 \\
4900\end{array}$ \\
\hline 18 months & $\begin{array}{l}\hat{\delta} \\
\text { o+ }\end{array}$ & $\begin{array}{l}328 \\
269\end{array}$ & $\begin{array}{l}32 \\
50\end{array}$ & $\begin{array}{l}113 \\
122\end{array}$ & $\begin{array}{l}639 \\
657\end{array}$ & $\begin{array}{l}5410 \\
4440\end{array}$ \\
\hline
\end{tabular}

* The weight of the bone marrw was expressed as $1.65 \%$ of body weight according to WATANABE (1955). 


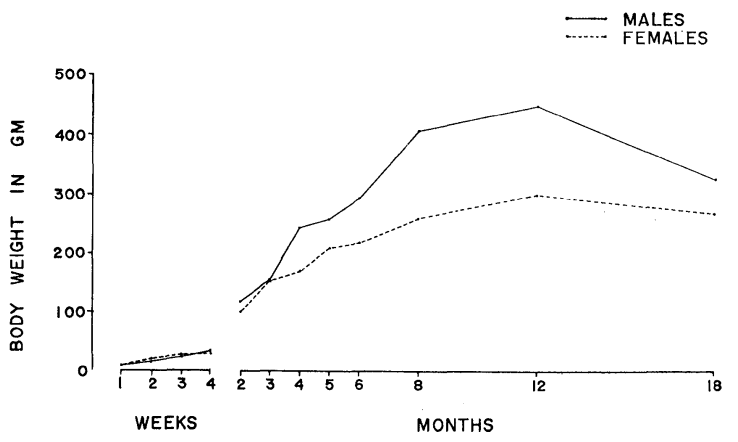

Fig. 1. Age changes in body weight in male and female albino rats of a modified WISTAR strain.
に，雄では 4 月目に極大 となり，以後漸減する (表 1,2; 図2).

胸腺の発育之退化の推 移をより正確に把握する ために，体重 $100 \mathrm{~g}$ あた りの胸腺の相対的重量之 相対的有核細胞総数の変 動を調べてみると，それ らの值の変動曲線は雌で は生後 2 週目に, 雄では 生後 3 週目に頂点に達

し，以後急凁に下降する（図 6,7)。な抢，乙れらの值からみた胸腺の発育の度合 いは生後 3 週目を除き，いずれの時期においてもつね踓が雄をしのいでいて， 明䐲な性差が認められる (図 6,7).

Table 2. Number of nucleated cells (in millions) per mg and per organ in the and bone marrow of male and female albino rats of a modified WISTAR

\begin{tabular}{|c|c|c|c|c|c|c|}
\hline \multirow{2}{*}{\multicolumn{2}{|c|}{ Age and sex }} & \multicolumn{2}{|c|}{ Thymus } & \multicolumn{2}{|c|}{ Mesenteric lymph nodes } & \multirow{3}{*}{$\begin{array}{c}\text { Spleen } \\
\text { fer } \mathrm{mg} \\
1.8 \pm 0.2 \\
2.0 \pm 0.2\end{array}$} \\
\hline & & per $\mathrm{mg}$ & per organ & per mg & per organ & \\
\hline 1 week & $\begin{array}{l}\hat{0} \\
\text { +9 }\end{array}$ & $\begin{array}{l}3.8 \pm 0.1 \\
3.9 \pm 0.2\end{array}$ & $\begin{array}{l}72.3 \pm 6.3 \\
83.7 \pm 11.2\end{array}$ & $\begin{array}{l}1.1 \pm 0.1 \\
1.1 \pm 0.1\end{array}$ & $\begin{array}{l}5.5 \pm 1.5 \\
7.3 \pm \quad 2.5\end{array}$ & \\
\hline 2 weeks & $\begin{array}{l}\hat{0} \\
\text { 早 }\end{array}$ & $\begin{array}{l}3.6 \pm 0.2 \\
3.6 \pm 0.4\end{array}$ & $\begin{array}{l}191.2 \pm \quad 9.6 \\
234.2 \pm 37.5\end{array}$ & $\begin{array}{l}1.1 \pm 0.6 \\
1.5 \pm 0.3\end{array}$ & $\begin{array}{l}11.0 \pm 2.4 \\
37.8 \pm 10.6\end{array}$ & $\begin{array}{l}1.7 \pm 0.2 \\
1.7 \pm 0.1\end{array}$ \\
\hline 3 weeks & $\begin{array}{l}\hat{\circ} \\
\text { 우 }\end{array}$ & $\begin{array}{l}3.8 \pm 0.3 \\
3.8 \pm 0.1\end{array}$ & $\begin{array}{l}370.0 \pm 69.9 \\
284.0 \pm 24.8\end{array}$ & $\begin{array}{l}1.6 \pm 0.1 \\
1.8 \pm 0.1\end{array}$ & $\begin{array}{r}50.0 \pm 8.7 \\
103.3 \pm 28.1\end{array}$ & $\begin{array}{l}1.6 \pm 0 \\
1.6 \pm 0.1\end{array}$ \\
\hline 4 weeks & $\begin{array}{l}\hat{\delta} \\
\text { 우 }\end{array}$ & $\begin{array}{l}4.0 \pm 0.2 \\
3.6 \pm 0.1\end{array}$ & $\begin{array}{l}344.8 \pm 23.8 \\
348.7 \pm 29.2\end{array}$ & $\begin{array}{l}2.1 \pm 0.2 \\
1.9 \pm 0.5\end{array}$ & $\begin{array}{l}114.4 \pm 31.2 \\
131.8 \pm 22.6\end{array}$ & $\begin{array}{l}1.9 \pm 0.2 \\
1.9 \pm 0\end{array}$ \\
\hline 2 months & $\begin{array}{l}\text { 昘 } \\
\text { + }\end{array}$ & $\begin{array}{l}3.4 \pm 0.1 \\
3.8 \pm 0.2\end{array}$ & $\begin{array}{l}707.4 \pm 55.6 \\
848.4 \pm 57.7\end{array}$ & $\begin{array}{l}2.2 \pm 0.1 \\
2.4 \pm 0.1\end{array}$ & $\begin{array}{l}402.1 \pm 63.4 \\
503.6 \pm 111.0\end{array}$ & $\begin{array}{l}1.7 \pm 0.1 \\
2.0 \pm 0.1\end{array}$ \\
\hline 3 months & $\begin{array}{l}\text { 昘 } \\
\text { 우 }\end{array}$ & $\begin{array}{l}3.8 \pm 0.4 \\
3.9 \pm 0.3\end{array}$ & $\begin{array}{r}817.5 \pm 90.8 \\
1137.2 \pm 118.1\end{array}$ & $\begin{array}{l}2.8 \pm 0.2 \\
2.5 \pm 0.1\end{array}$ & $\begin{array}{l}486.3 \pm 61.7 \\
562.4 \pm 55.6\end{array}$ & $\begin{array}{l}1.6 \pm 0.1 \\
1.7 \pm 0.1\end{array}$ \\
\hline 4 months & $\begin{array}{l}\hat{0} \\
\text { p+ }\end{array}$ & $\begin{array}{l}3.9 \pm 0.1 \\
3.8 \pm 0.2\end{array}$ & $\begin{array}{r}1126.5 \pm 154.4 \\
912.3 \pm 175.7\end{array}$ & $\begin{array}{l}2.5 \pm 0.1 \\
2.4 \pm 0.2\end{array}$ & $\begin{array}{r}1045.8 \pm 223.0 \\
830.7 \pm 64.1\end{array}$ & $\begin{array}{l}1.6 \pm 0.1 \\
1.5 \pm 0.1\end{array}$ \\
\hline 5 months & $\begin{array}{l}\hat{\circ} \\
\text { 우 }\end{array}$ & $\begin{array}{l}3.2 \pm 0.2 \\
3.6 \pm 0.4\end{array}$ & $\begin{array}{l}622.9 \pm 56.1 \\
727.8 \pm 171.9\end{array}$ & $\begin{array}{l}2.1 \pm 0.1 \\
2.6 \pm 0.4\end{array}$ & $\begin{array}{l}554.8 \pm 96.2 \\
769.5 \pm 119.0\end{array}$ & $\begin{array}{l}1.3 \pm 0.1 \\
1.7 \pm 0.3\end{array}$ \\
\hline 6 months & $\begin{array}{l}\hat{\mathrm{O}} \\
\text { 우 }\end{array}$ & $\begin{array}{l}3.8 \pm 0.3 \\
3.5 \pm 0.2\end{array}$ & $\begin{array}{l}675.8 \pm 43.5 \\
768.2 \pm 39.7\end{array}$ & $\begin{array}{l}2.5 \pm 0.3 \\
2.6 \pm 0.2\end{array}$ & $\begin{array}{l}678.4 \pm 37.0 \\
844.4 \pm 67.3\end{array}$ & $\begin{array}{l}1.5 \pm 0.1 \\
1.5 \pm 0.1\end{array}$ \\
\hline 8 months & $\begin{array}{l}\hat{0} \\
\hat{+}\end{array}$ & $\begin{array}{l}3.0 \pm 0.1 \\
3.3 \pm 0.1\end{array}$ & $\begin{array}{l}560.1 \pm 81.8 \\
564.1 \pm 41.5\end{array}$ & $\begin{array}{l}2.5 \pm 0.2 \\
2.4 \pm 0.1\end{array}$ & $\begin{array}{l}562.1 \pm 96.6 \\
441.7 \pm 22.9\end{array}$ & $\begin{array}{l}1.3 \pm 0.1 \\
1.2 \pm 0.1\end{array}$ \\
\hline 12 months & $\begin{array}{l}\hat{\circ} \\
\text { 우 }\end{array}$ & $\begin{array}{l}2.8 \pm 0.2 \\
2.9 \pm 0.2\end{array}$ & $\begin{array}{l}336.6 \pm 89.6 \\
334.9 \pm 70.3\end{array}$ & $\begin{array}{l}2.1 \pm 0.1 \\
2.2 \pm 0.1\end{array}$ & $\begin{array}{l}407.4 \pm 59.2 \\
339.2 \pm 11.9\end{array}$ & $\begin{array}{l}1.3 \pm 0.1 \\
1.3 \pm 0.1\end{array}$ \\
\hline 18 months & $\begin{array}{l}\hat{0} \\
\stackrel{+}{0}\end{array}$ & $\begin{array}{l}1.9 \pm 0.3 \\
2.1 \pm 0.4\end{array}$ & $\begin{array}{r}57.7 \pm 17.1 \\
115.8 \pm 35.9\end{array}$ & $\begin{array}{l}1.9 \pm 0.1 \\
1.8 \pm 0.2\end{array}$ & $\begin{array}{l}208.5 \pm 93.3 \\
214.2 \pm 20.6\end{array}$ & $\begin{array}{l}1.2 \pm 0.1 \\
1.2 \pm 0.1\end{array}$ \\
\hline
\end{tabular}


b) 腸間膜根リンパ節

（表 1,2；図 3,6,7).

腸間膜根リンパ節の 重量は雌雄と屯生後 2 月目に急增し, 4 月目 に最大となり，その後 漸減する。細胞密度の 值は生後 3 週間目まで はまだかなり低いが， 次第に上昇して，2月 目以後高い水準 (2.8一 $2.1 \times 10^{6} / \mathrm{mg}$ ）に保た れ, 12月以後漸減する. しかし，との細胞密度 の值は胸腺にくらべる

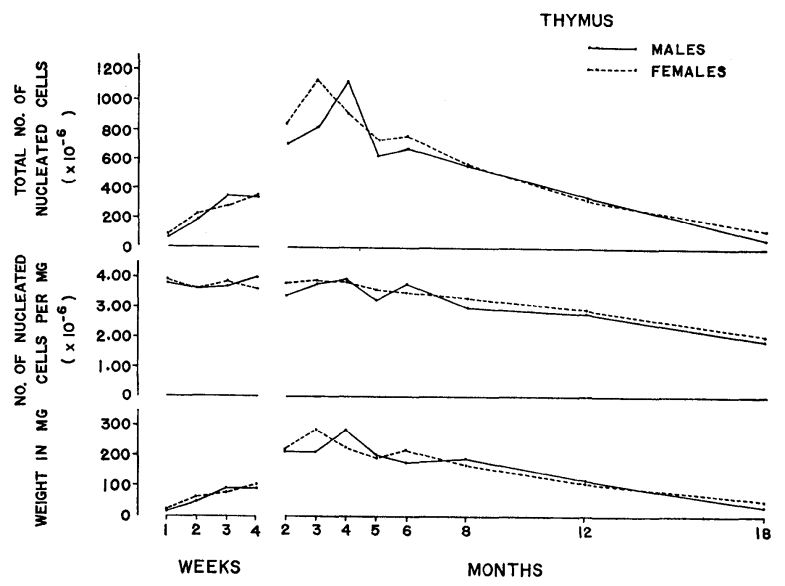

Fig. 2. Age changes in organ weight, cellular density (number of nucleated cells per $\mathrm{mg}$ ) and total number of nucleated cells in thymus of male and female albino rats of a modified WISTAR strain.

thymus, mesenteric lymph nodes, spleen strain. \pm standard error $(n=5)$.

\begin{tabular}{l|r|r}
\hline & \multicolumn{2}{|c}{ Bone marrow } \\
\hline per organ & per mg & \multicolumn{1}{|c}{ per organ } \\
\hline $56.0 \pm 6.9$ & $2.3 \pm 0.2$ & $363.1 \pm 61.2$ \\
$53.3 \pm 5.1$ & $2.8 \pm 0.5$ & $413.0 \pm 64.3$ \\
$73.4 \pm 11.0$ & $1.9 \pm 0.1$ & $541.2 \pm 20.3$ \\
$101.7 \pm 12.7$ & $2.2 \pm 0.2$ & $732.7 \pm 75.1$ \\
$153.6 \pm 23.2$ & $2.3 \pm 0.2$ & $975.1 \pm 103.0$ \\
$177.9 \pm 17.3$ & $1.9 \pm 0.1$ & $906.5 \pm 74.1$ \\
$156.9 \pm 12.4$ & $2.0 \pm 0.1$ & $1111.3 \pm 85.3$ \\
$188.8 \pm 36.1$ & $1.9 \pm 0.1$ & $1073.0 \pm 89.1$ \\
$502.2 \pm 97.1$ & $2.2 \pm 0.1$ & $4443.2 \pm 313.2$ \\
$543.6 \pm 105.2$ & $2.2 \pm 0.1$ & $3662.1 \pm 119.7$ \\
$734.2 \pm 49.6$ & $2.0 \pm 0.1$ & $5120.2 \pm 413.6$ \\
$920.5 \pm 274.7$ & $2.2 \pm 0.1$ & $5505.9 \pm 416.4$ \\
$843.5 \pm 129.6$ & $2.1 \pm 0.2$ & $7996.4 \pm 568.8$ \\
$745.9 \pm 49.2$ & $2.5 \pm 1.3$ & $6859.2 \pm 438.0$ \\
$785.8 \pm 52.3$ & $1.8 \pm 0.1$ & $7854.9 \pm 566.3$ \\
$850.3 \pm 121.4$ & $2.0 \pm 0.1$ & $6869.0 \pm 473.8$ \\
$989.9 \pm 129.1$ & $1.9 \pm 0.1$ & $9012.7 \pm 470.3$ \\
$842.5 \pm 53.4$ & $1.9 \pm 0.1$ & $6642.5 \pm 495.4$ \\
$683.3 \pm 38.2$ & $1.7 \pm 0.1$ & $11238.5 \pm 1118.7$ \\
$574.2 \pm 58.0$ & $1.6 \pm 0.1$ & $6958.6 \pm 341.3$ \\
$825.6 \pm 83.9$ & $1.6 \pm 0.1$ & $11903.9 \pm 913.8$ \\
$706.6 \pm 102.3$ & $1.7 \pm 0.1$ & $8011.0 \pm 530.7$ \\
$774.7 \pm 67.6$ & $1.3 \pm 0.1$ & $7279.2 \pm 1000.2$ \\
$791.2 \pm 159.1$ & $1.2 \pm 0.1$ & $5364.2 \pm 671.7$ \\
& &
\end{tabular}

之，一般に低い。有核細胞総数は, 䧳雄と6生後 2 月目から急速に増 大し，4月目に最大になり，以後 徐々に減少の傾向を示しながらあ 生後8月目まではな掠高い水準 に保たれ，以後減少する（表 1,2; 四 3).

体重 $100 \mathrm{~g}$ あたりの相対的重量 之相対的有核細胞総数の值は生後 3-4 週目加ら急上昇し, 生後 4 月 目に最高となり，以後漸減する （図 6,7). 乙れは胸腺の場合にく らべて著しい違いである。なお, これらの值からみた発育の度合い の性差は胸腺におけると同様に著 明で，いかなる時期においても䧳 の值が雄の值をしのいでいる（网 6, 7).

c）脾（表 1,$2 ;$ 図 4,6,7). 脾の重量の年令的推移は前 2 者 とはやや趣を異にしている。すな 


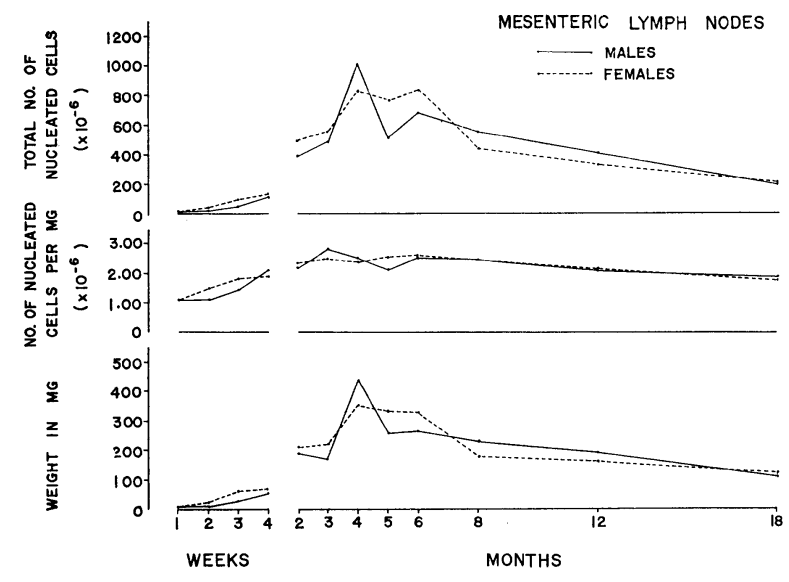

Fig. 3. Age changes in organ weight, cellular density (number of nucleated cells per $\mathrm{mg}$ ) and total number of nucleated cells in mesenteric lymph nodes of male and female albino rats of a modified WISTAR strain.
わち, 脾の重量は生 後 2 月目に急增し, 雌では 5 月目, 雄で は6月目に最大にな り，18月目に至るま でほぼ同じ水準を保 つ. 細胞密度は雌雄 と屯, 生後 1 週目加 らすでにかなり高值 $\left(2.0-1.5 \times 10^{6} / \mathrm{mg}\right)$ を示し, 生後 6 月目 までほぼ同じ水準に 保たれ, その後㴬減 する。ただし，細胞 密度の值は胸腺や腸

間膜根リンパ節のそれにくらべて著しく低い，有核細胞総数は䧳雄とも生後 3 6 月の間に著増し, 8 月以後やや減少する (表 1,2; 図 4).

体重 $100 \mathrm{~g}$ あたりの相対的重量之相対的有核細胞総数の值は, すでに生後 1 週 目から著しく高く, 生後 3 月目までこのような高い值を保持し，その後漸減する

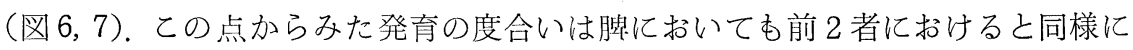
雌が雄を上迴わって おり，明瞭な性差が 認められる(図6,7).

d) 骨髄 (表 1,2; 図 5,7).

骨髄の重量は, 既 述のごとく，体重の $1.65 \%$ として算出さ れたので, その生後 の変動曲線が体重 の变動曲線に類似す るのは当然である (図1 と5), 骨䯣の細 胞密度は, 生後 1 週 目からすでに高い值 $\left(2.0 \times 10^{6} / \mathrm{mg}\right)$ を示 し, 生後 2-4月まで

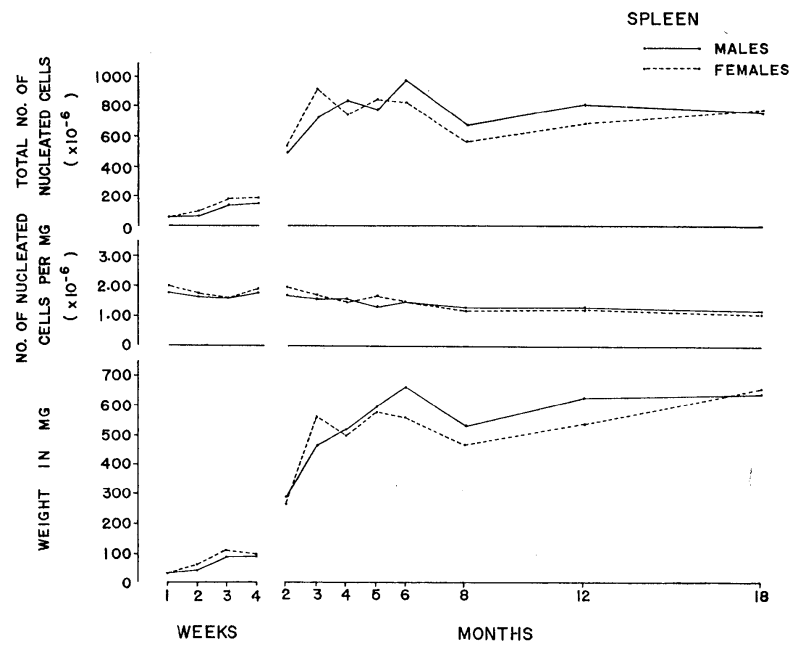

Fig. 4. Age changes in organ weight, cellular density (number of nucleated cells per $\mathrm{mg}$ ) and total number of nucleated cells of spleen of male and female rats of a modifred WISTAR strain. 
ほぼ同様な水準に保 たれるが，5月後か ら漸減しはじめ, 12 月をすぎると減少の 傾向がさらに強くな る. 骨骾の有核細胞 総数は生後 2 月目以 後急増し, $4-12$ 月 目にわたって高い水 準に保たれ, その後 漸減する.しかし，て こで考慮すべき事柄 は骨髄における脂肪 組織の存在で, 生後 5 月以後の骨髄には 脂肪組織が著しく増 加する（そのため生 後 5 月目以後細胞密
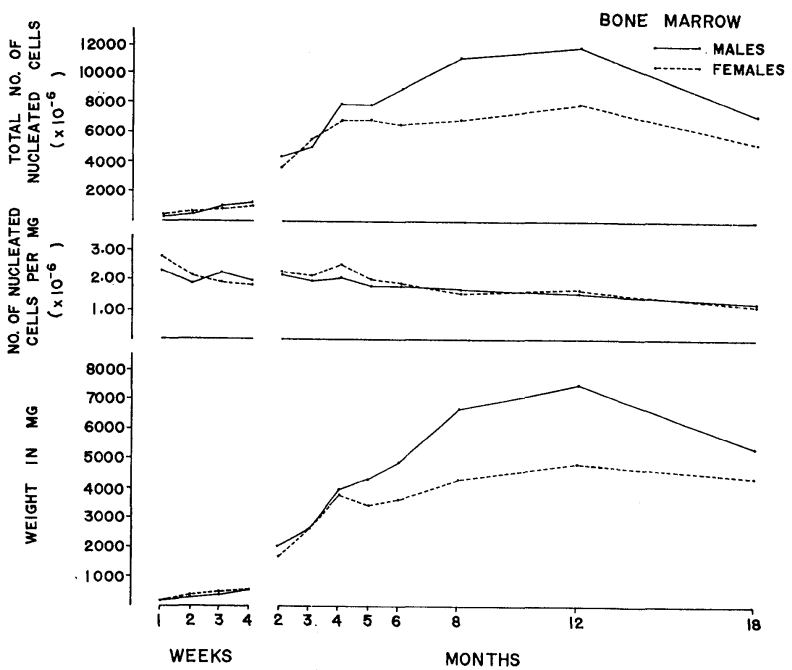

Fig. 5. Age changes in organ weight, cellular density (number of nucleated cells per $\mathrm{mg}$ ) and total number of nucleated cells in bone marrow of male and female albino rats of a modified WISTAR strain. The weight of the bone marrow was expressed as $1.65 \%$ of body weight according to WATANABE (1955).

度が低下してくる）が，ここでは全年令を通じて骨骾はすべて赤色骾，すなわち 造血能旺盛な骨骾と仮定して計算したので, 生後 5 月目以後の骨䯣の有核細胞総 数は著しく過大に見積もられているわけである.

体重 $100 \mathrm{~g}$ に対する相対的有核細胞総数の值は, 生後 1 週目から 4 月目まで著 しく高く，その後に漸減する（図 7)。乙れは脾に打ける傾向とよく似ている，骨

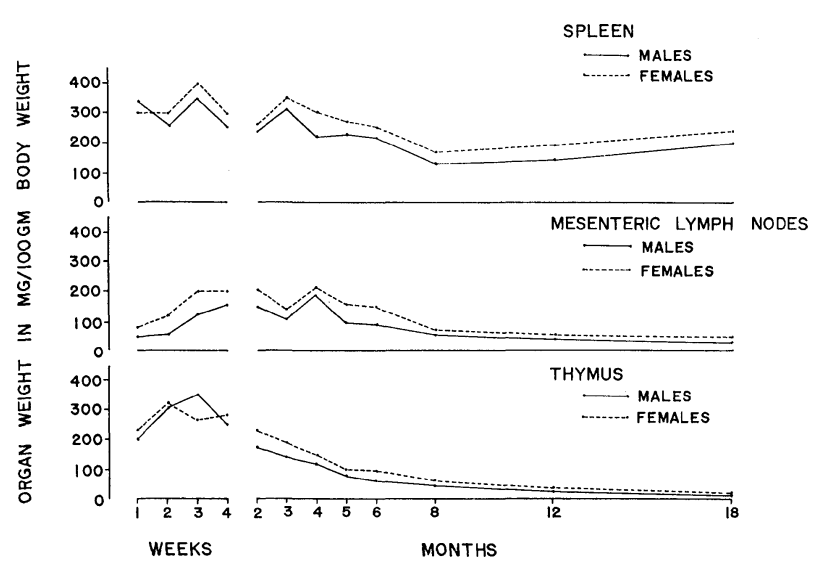

Fig. 6. Age changes in the relative weights (milligrams per 100 grams of body weight) of the thymus, mesenteric lymph nodes and spleen of male and female albino rats of a modified WISTAR strain.
髄では胸腺リンパ 組織汇認められた ような性差は明瞭 でなかった。なお， 図6 亿は骨䯣の相 対的重量を示さな かったが，それは 骨髄の重量が体重 の $1.65 \%$ として計 算されたあので, 実際の測定值では ないからである。 また, 骨䯣の有核 細胞総数も同様に 


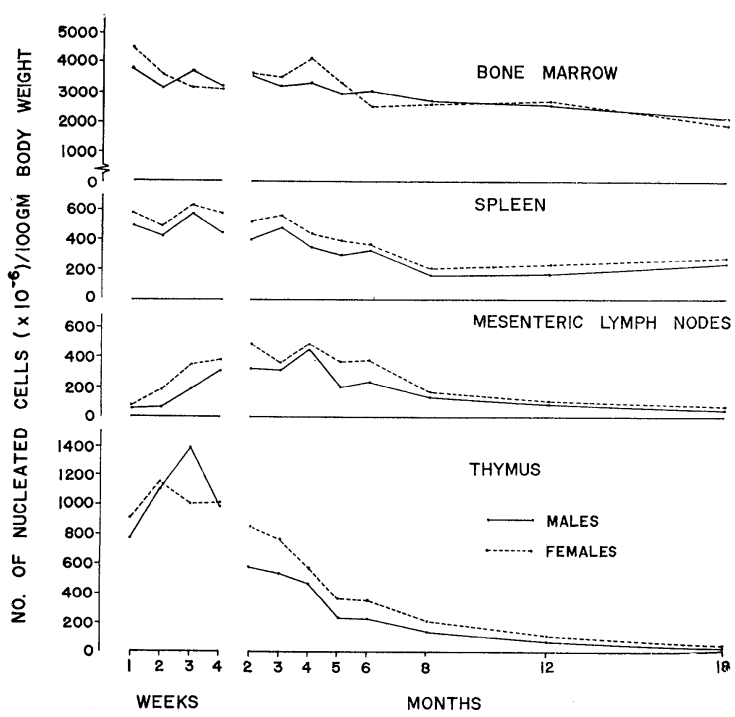

Fig. 7. Age changes in the ralative total number of nucleated cells ( $\times 10^{6}$ per 100 grams of body weight) in the thymus, mesenteric lymph nodes, spleen and bone marrow of male and female albino rats of a modified WISTAR strain.
して計算されたものであ るから, 胸腺リンパ組織 における実測值と比較す る場合には（図 7)，この ことを考虑に入れねばな らない。

\section{C. 組織学的所見から みた造血組織の年 令による変化.}

a) 胸腺.

胸腺の分化は他のリン パ組織よりも著しく早く 完了する。生後 1 週目の 胸腺は皮質が実質の大部 分をしめ, 髄質はわずか である(図8). 生後 3 週 目に注髄質もよく発達し てほぼ完成に近い構造を示し，以後䯣質の相対的增加が著明となる（図 9, 10). しかし定量的にみると，胸腺は生後2-3週目からすでに退化任向かうのであるか ら (図 6,7), 皮質の発育が䯙質をしのいでいる生後 $1-2$ 週目の状態が胸腺の正常 像であって，䯣質の相対的増加は胸腺の退化現象とみなすととができるが，ての ことは今後充分に検討する必要がある。生後 5 月以後には間質の増加が目立ち, 以後実質は次第に退縮して，脂肪組織によっておきかえられ，18月目になると実 質はわずかに残存するにすぎない（図11）.

b) 腸間膜根リンパ節.

リンパ節の年令による変化をみるうえに組織学上とくに重要なのは，2 次小節 の分化の程度である(尾兽越ら，1953，Awaya 1956，Imamura 1959)，そこで，私 は 2 次小節の形態変化についてすとし辣しく説明しておきたい，てのてとについ ては堀井と川上 (1963) のくわしい解説があるが，乙こでは粱屋 (1956) と今村

Fig. 8. Thymus of a 1-week-old rat. Note four lobules, each of which consists predominantly of a cortical area merging into a very small portion of medulla. The greater majority of cells are thymocytes or small lymphocytes. Rat No. 76, 우. $\times 78$.

Fig. 9. Thymus of a 3-week-old rat. Note a cortex filled solidly with lymphocytes and a slightly enlarged medullary portion showing beginning age involution. Rat No. 33 , 우. $\times 55$.

Fig. 10. Thymus of a 3-month-old rat. Note a relative enlargement of the medullary portion, showing further advanced age involution. Rat No. 93, 우. $\times 55$.

Fig. 11. Thymus of a 18-month-old rat. The atrophic parenchyma surrounded by fat and connective tissues, showing high grade age involution. Rat No. $18 \mathrm{M}-1, \hat{0} . \times 78$. 


（1959）の記載に従って述べるととにする。乙れによると，2次小節は発育の程度 によって次の 6 種類に分類される.

1. 成熟型または Flemming 型 2 次小節 (mature secondary nodules または Flemming's secondary nodules).

これは組織学の教科書に示される定型的な 2 次小節で, 比較的大型のリンパ球, 主として中リンパ球と細網細胞の集団からなる明中心と，乙れをとりかてむ小リ ンパ球の密集層 (暗殸) の 2 部から構成されるもので, 明中心の活動状態によっ てさらにつぎの 3 型にわけられる.

$1^{\circ}$ 活性型 2 次小節 (active mature secondary nodules). これは明中心が主とし て分裂の旺盛な中リンパ球 (中型リンパ型球) の集団からなるもので, 細網細胞 は比較的すくない（図 12).

$2^{\circ}$ 半活性型 2 次小節 (half-active mature secondary nodules). 明中心の半分が 分裂の旺盛な中リンパ球の集団からなり，他の半分はそのような活性を示さぬ細 網細胞によってしめられているもので，乙の場合には非活性部は必ずリンパ節の 表面に近く位置している(図 13).

$3^{\circ}$ 非活性型 2 次小節 (inactive mature secondary nodules). 明中心がほとんど細 網細胞のみからなり, 分裂活性が認められないもので, Hellmanのいう反応中心 に相当する (図 14).

2. 未熟 2 次小節 (immature secondary nodules). これは裸芽中心 (bare germinal center of Conway, 1937）とあよばれるもので, 主として分裂の旺盛な中リンパ球 (中型リンパ芽球)の集団からなり，小リンパ球からなる周囲の暗殼を欠いてい る。乙れは上述の活性型 2 次小節から暗殼を除いた像を示し, 成熟型 2 次小節の 発育の初期の段階にあたるものである。未熟 2 次小節は上述の活性型 2 次小節と と屯にリンパ球造血の盛んなときに出現する（図15).

3. 充実型 2 次小節 (solid secondary nodules of Groll and Krampf, 1920-1921). これは小リンパ球のみからなる円形の集団で, 明中心を欠くあのをいう（図 16).

4. 偽 2 次小節 (pseud-secondary nodules of Ehrich, 1929). これはビマン性のリ ンパ組織の比較的よくまとまった大きな集団で, ときにその周辺部に数個の充実

Fig. 12. An active from of a mature secondary nodule of the FLEMMING type. Mesenteric lymph node cortex of a 3-month-old rat. Note the pale-staining center composed of densely packed, medium-sized lymphocytes with many mitotic figures. Rat No. 92, 우. $\times 110$.

Fig. 13. A half-active form of a mature secondary nodule of the FLEMMING type. Mesenteric lymph node contex of a 4-month-old rat. Note that the pale-staining center is half active and half non-active. Rat No. $4 \mathrm{M}-2$, $0 . \times 110$.

Fig. 14. Two non-active forms oi mature secondary nodules of the FLEMMING type. Mesenteric lymph node cortex of a 12-month-old rat. The centers are mainly composed of reticular cells and devoid of proliferating lymphocytes. Rat No. 12M-8, $\hat{\delta} . \times 78$.

Fig. 15. An immature secondary nodule without outer zone of small lymphocytes (bare germinal center of $C O N W A Y)$, consisting nearly exclusively of medium sized lymhocytes. Mesenteric lymph node cortex of a 3 -week-old rat. Rat No. 33, 우. $\times 160$. 

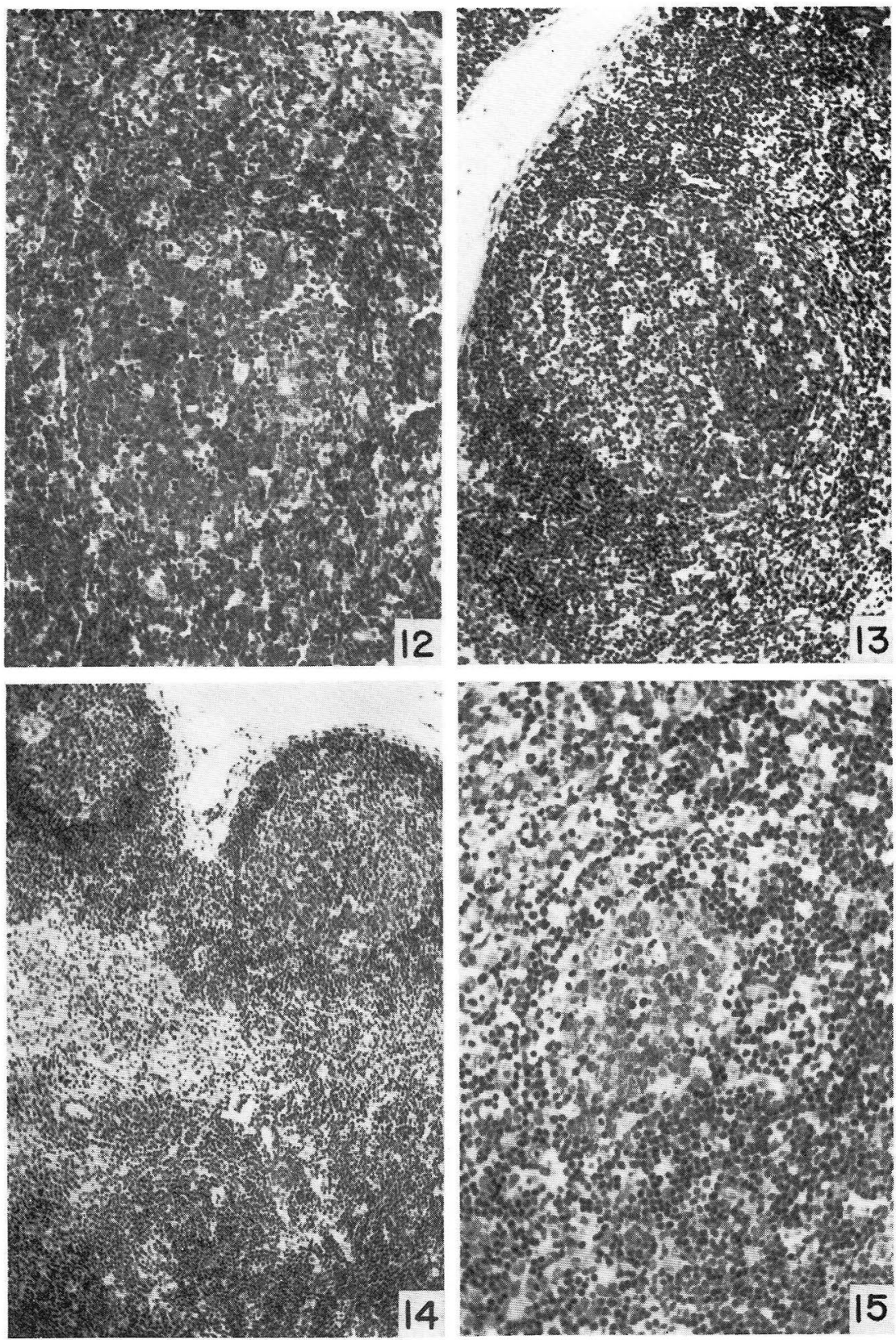
型 2 次小節や成熟型 2 次小節を具える（図 16）. 偽 2 次小節のなかには立方上皮 に似た背の高い内皮細胞をむった毛細管後静脈 (postcapillary vein) が存在する のが特徴である（図 17）。乙のものは充実型 2 次小節とともにリンパ節の分化の 初期にみられる。

さて，腸間膜根リンパ節は生後 1 週目まではビマン性のリンパ組織にすぎない が，2 週目になると皮質に充実型 2 次小節や偽 2 次小節があらわれる。乙の時期 には未熟 2 次小節が出現しはじめ, このものは生後 3-4 週目になると著しく増 加する。 その後, 充実型 2 次小節や偽 2 次小節は相対的に減少し, 生後 2 月目に なると, 定型的な成熟型 2 次小節が多数出現するようになり，3-4 月目にはほぼ 発達の極限に達する。乙の時期にみられる成熟型 2 次小節は活性型や将活性型が 大多数をしめ, リンパ球造血の旺盛なととを示す。ところが, 生後 5一6月目に なる之，非活性型が混在しはじめ，8月以後には非活性型が大多数をしめる，そ して生後 18 力月に至れば, 2 次小節の数も大きさも著減し, 非活性型 2 次小節が 皮質に散在するにすぎない，ただし例外として，生後 12 月においてす半活性型 2 次小節がかなり多数残存することあある.

ここで注目すべきととは, 未熟 2 次小節や成熟型 2 次小節のうちで活性型また は半活性型の増生が目立つ時期, すなわち生後 2 月から 4 月にかけて, リンパ節 の重量, 細胞密度および細胞総数が同時に著増することである. 生後 5 月以後, 2 次小節の分化が完了したのちは, 上記の諸測定值も漸減するととは既述の通り である。ラットに拉けるこのような 2 次小節の生後分化の状態は家鬼における観 察 (Awaya 1956) とほぼ同様である.

以上のような 2 次小節の形態変化のほかに, 腸間膜根リンパ節には年令の進む につれて皮質之髄質の割合の変化, 形質細胞の出現などがみられる。すなわち, 生後 2 週目までは皮質が髄質を圧倒的に凌駕しているが，その後の加齢につれて 皮質に対する䯣質の割合は次第に増加する。そして，増加した髄質の髄索には生 後 4 週目から形質細胞が出現しはじめ, 2月以後には著明に増加する。このような 形質細胞の発現と増加については後日詳述の予定である (粟屋と堀, 未発表).

c) 脾.

蜰の白䯣における 2 次小節の形態は腸間膜根リンパ節の場合とほぼ同様である が，その分化の時期はおくれる。すなわち，未熟 2 次小節はいわゆる周動脈リン

Fig. 16. A pseudo-secondary nodule with several solid secondary nodules. Mesenteric lymph node of a 3-week-old rat. Rat No. 31, ㅇ․ $\times 78$.

Fig. 17. A post-capillary vein with extraordinarily large, oval endothelial cells (in the center of the figure). It contains some small lymphocytes. Greater magnification of the center portion of Fig. 16. $\times 320$.

Fig. 18. Periarterial lymphoid sheaths seen in an early stage of development of splenic white pulp. Spleen of a 4-week-old rat. Rat No. 7 , 今. $\times 55$.

Fig. 19. A germinal center just developing in the periarterial lymphoid sheath. The same spleen as Fig. 18. $\times 160$. 



6. *6.

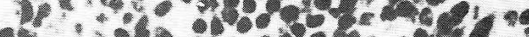

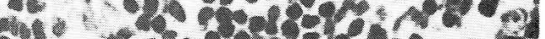
- to 0 - 20 -





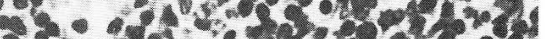

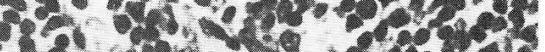

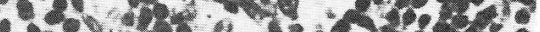

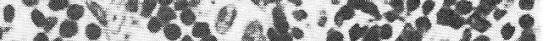

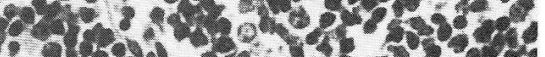

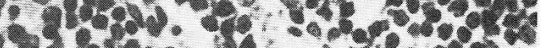

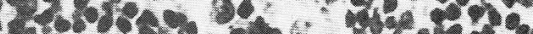
-

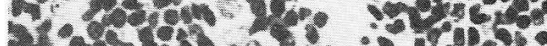



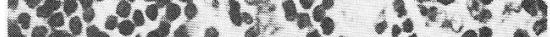



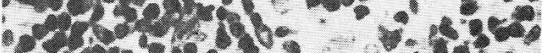

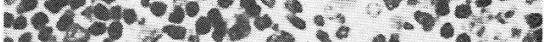

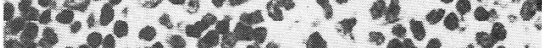

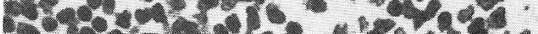

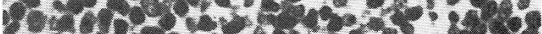

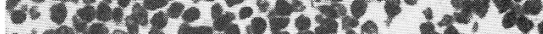

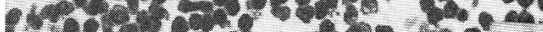

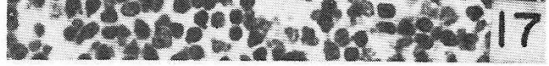

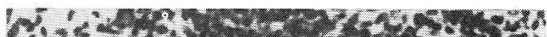

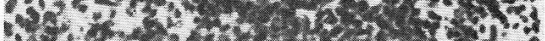

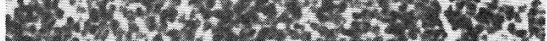

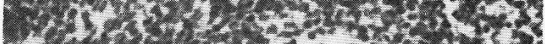

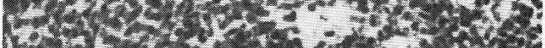

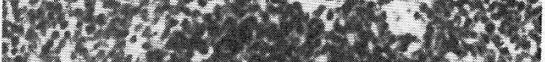



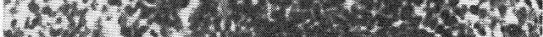



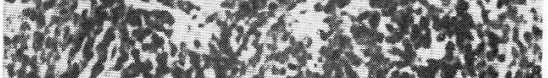

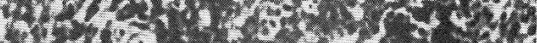



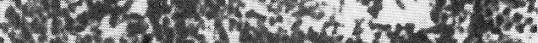
$x^{2}+3 x+3 x+3 x-700$

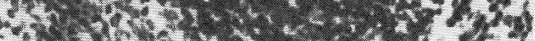





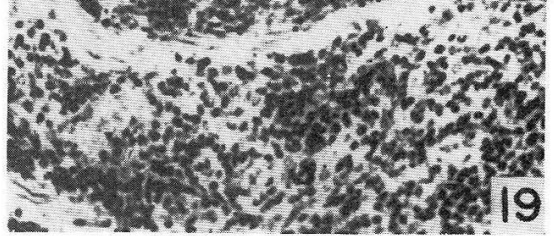


パ鞘 (periarterial lymphoid sheath) のなかに中リンパ球の小集団として生後 4 週 目にはじめて現われる（図 18,19）. 成熟型 2 次小節は生後 2 月目から出現しはじ め, 生後 4 月目には活性型括よび半活性型 2 次小節が著しく増加する. その後, 非活性型のものが多くなり，2 次小節は次第に数と大きさを減ずる.

なお，ラットの赤脾髄には多かれ少なかれ骨髄球や赤芽球からなる骨骾外造血 巣が認められる。そしててのような髄外造血は2 次小節が充分発達していない生 後 3 週目まではかなり著明であるが, 生後 $2-4$ 月に 2 次小節の分化が頂点に達 する時期には衰退し，2次小節が退化しはじめる 5 月以後には再び増勢に転ずる.

d) 骨髄.

骨䯣における細胞構成の年令的推移をみると, 生後 3 月目までは赤芽球系の細 胞が多く，顆粒球系の細胞が少ない．その後加齢につれて次第に顆粒球系の細胞 が多くなり, 赤芽球系細胞が少なくなり, 老年になるにつれて顆粒球系がふえて, 顆粒球-赤血球比（M/E-ratio）が大きくなる.

なお，骨髄にはかなり早くから脂肪細胞が認められるが，骨髄の脂肪化は紐胞 密度が低下しはじめる 5 月以後に招いて次第に著明となる。

\section{III. 考察.}

造血組織, とくに胸腺リンパ組織の発育と退化の状沉を体重 $100 \mathrm{~g}$ あたりの各 器官の相対的重量と相対的有核細胞総数の変動曲線について調べてみると, 器官 の種類によってかなりの差異が認められる。とくに注目すべきてとは、リンパ性 器官のうちで胸腺がきわめて特異な発育と退化の過程を示すことである.

胸腺に打ける体重 $100 \mathrm{~g}$ あたりの相対的重量亡相対的有核細胞総数の変動曲線 は生後 1 週目から急上昇し雌では生後 2 週目に, 雄では生後 3 週目に頂点に達し, その後急速に下降する（図 6,7 ). このことは胸腺が生後 $2-3$ 週目までにあっと むつよく発育し，その後に退化に向かうととを示している。したがって，胸腺の 「生理的」退縮は従来考えられていたよりあずっと早期にあらわれるといわねば ならぬ. これに対して, 腸間膜根リンパ節の相対的重量と相対的有核細胞総数の 変動曲線は生後 3-4 週目に急上昇し, その後高い水準に保たれ, 雌雄と屯生後 4 月目に頂点に達し，その後次第に下降する，つまり，胸腺の発育が退化に向汃う 頃から，逆にリンパ節の発育は盛んとなるのである。乙のように，胸腺の発育が リンパ節の発育に先行することは, 胸腺の機能に関する最近の知見 (Archer と Pierce 1961, Miller 1961, 1962, janković ら 1962, Arnason ら 1962, 1962, Waksman ら 1962, Dameshek 1962, Burnet 1962, Good ら 1962, Dalmasso ら 1963, Parrott と East 1962, 1964, Sherman ら 1962, 1963) と関連して興味が深い. 今日では, 胸腺は抗体産生能をもたない第 1 次リンパ球 ('first level' lymphocyte) の産生場 所であって，そのようなリンパ球のリンパ節や脾への供給源であるとされており， 出生直後に胸腺を摘出した動物ではこれらのリンパ組織にリンパ球の定着がおこ 
らず，そのためにリンパ節や脾の発育不全をきたし，動物は免疫能を獲得できず， いわゆる wasting disease に㧍ちいるととが明らかとなった。本研究の成績はと のことを定量的な面から裏づけたむのといえる。

脾における体重 $100 \mathrm{~g}$ あたりの相対的重量之相対的有核細胞総数は, 生後 1 週 目加らすでに高値を示し, 生後 3 月目まで高い水準に保たれ, 以後急速に低下す る(図 6,7). しかし, 生後 $1-3$ 週目の赤脾䯣には骨䯣性細胞, とくに赤芽球が 多数存在するために, 脾の有核細胞総数の值がそのままリンパ組織の発育の度合 いを示すとはいえない.

他方, 組織学的所見についてみると, 胸腺では定量的な面からみてその発育が あっとも旺盛とみなされる生後 $1-2$ 週目には皮質領域の占める割合が圧倒的に 多く，䯣質の領域はきわめて少ないが，乙の時期をすぎると髄質の占める割合が 多くなり，完成型の胸腺像を示すようになる。すなわち，通常完成型と考えられ ている胸腺の組織像は定量的な面を併世考えると, 退縮期に入った像とみなすこ 之ができる。また，腸間膜根りンパ節に扔いても定量的にみて発育の盛んな生後 2-4 月においては未熟 2 次小節や活性 2 次小節の出現と増加がみられ, その後の 退化の過程においては非活性 2 次小節の増加がみら机る。脾においてもこれとほ ぼ同様な 2 次小節の分化之退化が観察せられる。乙のように，胸腺リンパ組織の 組織学的所見加らみた発育之退化の状況も既述の定量的所見にかなりよく一致し ているといえる.

骨髄における体重 $100 \mathrm{~g}$ あたりの有核細胞総数は生後 1 週目から 4 月目にかけ ては著しく高い水準にあるが，その後次第に減少する（図7).乙れは上述の脾に おりる所見とよく似ている。ただしての場合には，骨䯣の重量は体重の $1.65 \%$ \%で, しかもすべて赤色䯣として計算していることを考虑にいれる必要がある. 年令が 進むにつれて黄色䯣が著しく増加すると推定されるので, 骨䯣における老化現象 は本研究の成績が示すよりあ一層高度に扔てる筈である。

つぎに，造血組織の発育の性差についてみると，すでに述べたように，造血組 織の重量, 細胞密度抢よび有核細胞総数の年令的推移には一定の性差は認められ なかった（図2-5）が, 造血組織の体重 $100 \mathrm{~g}$ 亿対する相対的重量之相対的有核細 胞総数についてみると, 骨髄以外の造血組織, すなわち, 胸腺, 晹間膜根リンパ節 および脾に扔いてはつ权比雌の值が雄の值を上回っていた（図6,7). このととは, リンパ組織の発育に関するかぎり, 雌の方が雄より屯優位にあるてとを示してい る. 人間では一般に女性の平均寿命が男性のそれよりあ長いといわれているが, このととと生体の防衛機序に重要な役割を演ずるリンパ組織が男性におけるより あ女性に拉いてょく発育しているとととの間に密接な関係があるように思利机 る.しかし, これには性ホルモンの関与が大きいと推定されるので, な扔今後の検 討にまたねばならぬ。 


\section{IV. 結語.}

著者はWistar 亜系ラットについて, 造血組織の年令的推移を, 主として定量 的知見を基盤として検討した。造血組織, とくに胸腺リンパ組織の発育と退化の 推移をむっと屯明瞭に示すあのは, 体重 $100 \mathrm{~g}$ 当たりの相対的重量と相対的有核 細胞総数, とくに後者の変動である。それによると, 胸腺は生後 $2-3$ 週目に発 育の頂点に達し，以後退化に向かう。乙れに対して腸間膜根リンパ節，脾および 骨䯣は生後 2 月目から 4 月目にかけて著明に発育し，その後退化に向う。このこ とは胸腺の機能に関する最近の知見とよく一致して扝り，胸腺の早期退縮が他の リンパ組織, たとえば脾やリンパ節などのその後の発育に密接に関係しているこ とを示唆している。なお，胸腺リンパ組織における上述の值はいずれの年令にお いても雌が雄を上回る。

\section{Author's abstract.}

The postnatal growth and involution of the blood-forming tissues of the albino rats at different ages were studied chiefly by means of the quantitative analysis. One hundred and twenty rats of a subline of the WISTAR strain were used in this study. The animal material consisted of 12 different age groups; 1, 2, 3 and 4 weeks and $2,3,4,5,6,8,12$ and 18 months after birth, in groups of 10, 5 males and 5 females, on each occasion. These animals were bred in our own laboratories under optimal environmental conditions. Breeding animals were inspected twice weekly, pregnancies and birth were recorded, the young were weaned and the sexes were separated at 28 days of age. After stunning the thymus, mesenteric lymph nodes, spleen and bone marrow were removed from each animal, the estimation of the total number of nucleated cells in these organs being made according to the method described by AWAYA in 1962. At the same time, histological studies of section were also made of these organs.

The alterations of the absolute weight and number of nucleated cells in the individual organ in response to aging, i. e. age changes of the absolute growth and involution, are shown in Tables 1 and 2 and Figs. 2, 3, 4 and 5. There occurred a progressive absolute growth of these organs until the end of the 3rd or 4th month (6th month in spleen). This was followed by an absolute involution which continued throughout the succeeding ages studied. On the other hand, if the organ weight and the total number of nucleated cells were calculated relative to body weight, the pattern of the growth and involution curve was characteristic of the individual organ, the thymus in particular (Fig. 6 and 7). At the ages of the 2nd or 3rd week (in females and males, respectively), there occurred a maximal relative growth of the thymus, which was followed by a progressive age involution. This was distinctly different from growth curves of the mesenteric lymph nodes and spleen. The mesenteric lymph nodes initiated their development in this period. The growth was maintained until the end of the 3rd and 4th months in the spleen and mesenteric lymph nodes, respectively. This showed that the thymus underwent a very rapid physiological involution while the mesenteric lymph nodes and spleen were still growing. 
Recent work from several laboratories has established that the thymus plays an essential role in maturation of immunologic function and in the development of the anatomic integerity of the lymphoid tissues such as lymph nodes and spleen. Animals thymectomized at birth have a marked diminution of lymphocytes in their blood and tissues and severe defects in immune responses (ARCHER and PIERCE 1961, MILLER 1961, 1962, MARTINEZ et al. 1962, JANKOVIĆ et al. 1962, ARNASON et al. 1962, 1962, DAMESHEK 1962, BURNET 1962, GOOD et al. 1962, DALMASSO et al. 1963). These animals often develop a wasting syndrome, with failure of body growth and early mortality (GOOD et al. 1962, WAKSMAN et al. 1962, PARROTT and EAST 1962, 1964, SHERMAN et al. 1962, 1963). The results presented here support the above recent views on thymus function.

On the basis of per unit of body weight, the weights and the total numbers of nucleated cells in blood-forming tissues were found to be greater in females than in males throughout the period studied with the exception of bone marrow, although there were no sex differences in absolute values (Figs. 6 and 7). This indicates that the growth and involution of lymphatic tissue is influenced by sex factors.

Histologically, the thymus was made up of lobules, each of which consisted predominantly of a cortical area merging into a very small portion of medulla at the age of 1 or 2 weeks (Fig. 8), presenting normal adult architecture with a relative enlargement of a medullary portion at the age of 3 weeks (Fig. 9) when other lymphatic tissues were very incompletely developed. Since the thymus, from the quantitative views presented here, began to regress already beyond this time ( 3 weeks), the relative increase in a medullary portion herein might be regarded as a sign of involutionary changes. With advancing age occurred more gradual involution which was accompanied by a cortical thinning with a further relative enlargement of medulla and finally a reduction in the parenchyma and an increase of adipose tissue in the interlobular connective tissues (Fig. 10 and 11). Between 2 and 4 months of age, formation and maturation of secondary nodules in the mesenteric lymph nodes and splenic white pulp took place coincident with an absolute as well as relative increase in the organ weight and number of nucleated cells in respective organ (Figs. 12-19).

Thus, it is our opinion that the thymus is fully developed at the 2nd (or 3rd) week of age and thereafter undergoes a rapid physiological involution and that this phenomenon may be closely related with further growth of other lymphatic tissues. Further work on this problem is in progress.

\section{文献.}

Andreasen, E. : Studies on the thymolymphatic system. Acta path. microbiol. scand. (Kobenhavn) Suppl. 49. (1943). - Andrew, W.: Age changes in the vascular architecture and cell content in the spleens of 100 Wistar Institute rats, including comparisons with human material. Amer. J. Anat. 49 (1946). P. 1-74. - Andrew, W. and N. V. Andrew: Age changes in the deep cervical lymph nodes of 100 Wistar Institute rats. Amer. J. Anat. 82 (1948). P. 105-166. -Archer, 0. and J. C. Pierce: Role of thymus in development of the immune response. Fed. Proc. 20 (1961) P. 26. - Arnason, B. G., B. D. Janković, B. H. Waksman and C. Wennersten: Role of the thymus in immune reactions in rats. II. Suppressive effect of thymectomy 
at birth on reactions of delayed (cellular) hypersensitivity and the circulating small lymphocyte. J. exp. Med. 116 (1962). P. 177-186. - Arnason, B. G., B. D. Janković and B. H. Waksman : A survey of the thymus and its relation to lymphocytes and immune reactions. Blood 20 (1962). P. 617-628. - Awaya, K.: The mode of the lymphatic system to ovalbumin, with remarks on the role of secondary nodules in lymphocytopoiesis. Bull. Yamaguchi Med. Sch. 3 (1956). P. 115-143. - Estimation of the total number of nucleated cells in the blood-forming organs by cell-counting method. Okajimas Fol. anat. jap. 38 (1962). P. 263-270. 一 粟屋和彦: 造血組織の年令による変化：Wistar 系ラットと拈ける観察．老年病 7 (1963). 頁 779-786. 一 Awaya, K., H. Fujii, Y. Tanaka and M. Okada: Estimation of the total number of nucleated cells in the bone marrow of young adult albino rats. Arch. histol. jap. 18 (1960). P. 473477. - Awaya, K., M. Oda, S. Abe and M. Yoshimura: A simple method for evaluation of total cellular number in the thymolymphatic organs. Arch. histol. jap. 22 (1962). P. 203-207. Burke, W. T. and C. Harris: Total cell counts of the bone marrow of normal albino rats from 1 to 50 weeks of age. Blood 14 (1959). P. 409-414- Burnet, F. M.: The thymus gland. Sci. Amer. 207 (1962). P. 50-57. - Conway, E. A.: Cyclic changes in lymphatic nodules. Anat. Rec. 69 (1937). P. 487-513. - Dalmasso, A. P., C. Martinez, K. Sjodin and R. A. Good: Studies on the role of the thymus in immunobiology. Reconstitution of immunologic capacity in mice thymectomized at birth. J. exp. Med. 118 (1963). P. 1089-1109. - Dameshek, W.: The thymus and lymphoid proliferation. Blood 20 (1962). P. 629-632. - Ehrich, W. E.: Studies on the lymphatic tissue. I. The anatomy of the secondary nodules and some remarks on the lymphatic and lymphoid tissue. Amer. J. Anat. 43 (1929). P. 347-383. - Fand, I. and A. S. Gordon: A quantitative study of the bone marrow in the guinea pig throughout life. J. Morph. 100 (1957). P. 473-507. - Good, R. A., A. P. Dalmasso, C. Martinez, O. K. Archer, J. C. Pierce and B. W. Papermaster: The role of the thymus in development of immunologic capacity in rabbits and mice. J. exp. Med., 116 (1962). P. 773-796. - Grieshammer, W.: Beitrag zur Kenntnis des Verhaltens des lymphatischen Gewebes im Sauglings- und frühen Kindesalter. Beitr. path. Anat. 99 (1937). S. 283-304. - Groll, H. u. F. Krampf : Involutionsvorgänge an der Milzfollikeln. Zbl. Path. 31 (1920-1921). S. 145-159. - Gyllensten, L.: The postnatal histogenesis of the lymphatic system in guinea-pigs. Acta anat. 10 (1950). P. 130-160. - Hammar, J. A.: Zur Histogenese und Involution der Thymusdrüse. Anat. Anz. 27 (1905). S. 23-30, 41-89. - Hellman, T.: Lymphgefässe, Lymphknötchen und Lymphknoten. (Hgb. v.) Möllendorff: Handbuch der mikroskopischen Anatomie des Menschen. Bd. 6, Tl. 1. 1930. S. 233-396. 一 堀井五十雄と川上良澄：淋巴節の分布と発生. 日本血液学会：日本血液学会全 書. 巻 1. 1963. 頁 797-822. 一 Hwang, J. M. S., S. W. Lippincott and E. B. Krumbhaar: The amount of splenic lymphatic tissue at different ages. Amer. J. Path. 14 (1938). P. 809-819. - Imamura, H.: Further studies of a lymphocytic hemogram and its relation to lymphocytopoiesis. I. Variations in mitochondrial content of blood lymphocytes in relation to the postnatal development of the lymphatic apparatus in the rat. Okajimas Fol. anat. jap. 32 (1959). P. 119-131. 一伊東雅之：モルモットの胸腺の組織及び組織発生. 名古屋医学 73 (1957). 頁 214-235. 一 伊東一郎：家兔胸腺の組織発生学的研究. 名古屋医学 73 (1957). 頁 732-753. Jankovic, B. D., B. H. Waksman and B. G. Arnason: Role of the thymus in immune reactions in rats. I. The immunologic response to bovine serum albumin (antibody formation, Arthus reactivity, and delayed hypersensitivity) in rats thymertomized or splenectomized at various times after birth. J. exp. Med. 116 (1962). P.159-176. 一加納繁美：胸腺江関する研 究. I. 胸腺の年令的変化, 就中, その細胞学的研究. 京都大医. 第 2 解剖論集. 4 (1955).一 加藤鐐五郎：ラッテ胸腺の組織学的研究. 名古屋医誌. 58 (1943). 頁 471-504. 一 川崎一郎： 八ムスター胸腺の組織発生学的研究. 名古屋医学 77 (1959). 頁 227-251. 一 Krumbhaar, E. B. and S. W. Lippincott: The postmortem weight of the normal human spleen at different ages. Amer. J. med. Sci. 197 (1939). P. 344-358. - Martinez, C., J. Kersey, B. W. Papermaster and R. A. Good: Skin homograft survival in thymectomized mice. Proc. Soc. exp. 
Biol. Med. 109 (1962). P. 193-196. - Miller, J. F. A. P.: Immunological function of the thymus. Lancet 2 (1961). P. 748-749. 一 Miller, J. F. A. P.: Role of the thymus in transplantation immunity. Ann. N. Y. Acad. Sc. 99 (1962). P. 340-354. 一尾曾越文亮, 張 良治, 粟屋 和彦, 唐沢惟信：末梢血淋巴球に於ける含有ミトコンドリア数の年令による消長. 日血会誌. 16 (1953). 頁 293-298. — Österlind, G.: Über die Mengenverhältnisse der Sekundärknötchen in der Milz des normalen Kaninchens in verschiedenen Altersstufen. Z. Alterforsch. 2 (1940). S. 318-347. - Parrott, D. M. V. and J. East: Role of the thymus in neonatal life. Nature 195 (1962). P. 347-348. - Parrott, D. M. V. and J. East: The thymus and immunity. Proc. roy. Soc. Med. 57 (1964). P.147-151. - Santisteban, G. A.: The growth and involution of lymphatic tissue and its interrelationships to aging and to the growth of the adrenal glands and sex organs in CBA mice. Anat. Rec. 136 (1960). P. 117-126. - Sherman, J. D., M. M. Adner and W. Dameshek: Studies on thymectomized hamsters. Blood 20 (1962). P. 805. - Sherman, J. D., M. M. Adner and W. Dameshek: Effect of thymectomy on the goldenhamster (Mesocricetus Auratus). I. Wasting disease. Blood 22 (1963). P. 252-271. - Söderlund, G. u. A. Backman: Studien über die Thymusinvolution. Die Altersveränderung der Thymusdrüse beim Kaninchen. Arch. mikr. Anat. 73 (1909). S. 699-725. 一高見俊一郎：マウス胸腺の組織発生 学的研究. 名古屋医学. 76 (1958) 頁 806-829. 一 Waksman, B. H., B. G. Arnason and B. D. Jaković : Role of the thymus in immune reactions in rats. III. Changes in the lymphoid organs of thymectomized rats. J. exp. Med. 116 (1962). P. 187-206. 一渡辺健: 胸腺の研究. I. 白鼠胸腺重量の生理的変遷と体重括よび生殖腺発育との関係. 千葉医会誌. 7 (1929). 頁 981-1012. 一 渡辺静夫：骨髓の重量について，九血会誌５ 5 (1955). 頁 132-157. 